\title{
Analisa Kegagalan Pipa Udara A312 Tipe 304H pada Line A-1011-14" (25P2J) Unit Amonia PT. Petrokimia Gresik
}

\author{
Sopan Prayoga dan Witantyo \\ Jurusan Teknik Mesin, Fakultas Teknologi Industri, Institut Teknologi Sepuluh Nopember (ITS) \\ Jl. Arief Rahman Hakim, Surabaya 60111 Indonesia \\ e-mail:witantyo@me.its.ac.id
}

\begin{abstract}
Abstrak - Line A-1011-14" (25P2J) menggunakan pipa tahan karat TP304H berdiameter 14 inch. Pipa mengalami pecah saat beroperasi pada temperatur $8^{\circ} 0^{\circ} \mathrm{C}$ (overheating) dan crack ditemukan pada hampir semua sambungan las. Kegagalan pipa dievaluasi dengan metode RCFA (root cause failure analysis) didukung pengujian Metalografi, SEM-EDX, dan OES. Metode ini digunakan untuk mengetahui akar penyebab kegagalan pipa udara TP304H pada line A-1011-14” (25P2J). Hasil analisa didapat adanya pre-existing crack mengakibatkan tegangan pipa 12978.55 psi masih di bawah tensile strength material TP304H pada temperatur $800^{\circ} \mathrm{C}$ yaitu 18000 psi. Hasil pengujian SEM dan metalografi menyatakan bahwa, kegagalan yang terjadi pada las longitudinal diakibatkan adanya IGSCC (intergranular stress corrosion cracking) yang mengakibatkan batas butir mengalami sliding, dan terjadi penurunan kekuatan pada material. Adanya sensitisasi dibuktikan dengan pengujian EDX yang menunjukkan kenaikan persentase unsur krom dan karbon pada batas butir yaitu $1.4 \%$ dan $21.64 \%$. Untuk menghindari kegagalan yang sama, maka material TP304H welded pipe perlu diganti TP304H seamless pipe. Crack yang terjadi pada las circumferential diakibatkan adanya IP (incomplete penetration) yang menyebabkan tumbuhnya crack yang menjalar dari ujung IP menuju fusion zone, untuk mencegah hal tersebut maka setiap proses pengelasan yang dilakukan harus disesuaikan dengan prosedur.
\end{abstract}

Kata Kunci-304H, failure analysis, high temperature, precipitates

\section{PENDAHULUAN}

$\mathrm{P}$ IPE Line A1011-14"(25P2J) adalah penghubung antara outlet air heater 101-BCA 2 dengan secondary reformer 103-D yang merupakan saluran pipa tahan karat type $304 \mathrm{H}$ berdiameter 14 inch dan beroperasi pada themperatur $610^{\circ} \mathrm{C}$ dengan tekanan $39.7 \mathrm{~kg} / \mathrm{cm}^{2}$.

Mulai tahun 2004 sudah beberapa kali terjadi kegagalan pada line A1011-14” (25P2J). Kegagalan yang terjadi adalah retak (crack) pada sambungan lasan pipa. Perbaikan sementara yang dilakukan adalah melakukan re-inforce tambalan pelat dan penggantian beberapa pipa yang mengalami kegagalan. Salah satu contoh kasus kegagalan (failure) pada line A101114" (25P2J) yaitu pada tanggal 14 Januari 2015 pipa mengalami pecah atau meledak. Posisi pipa yang mengalami pecah berada dekat outlet air heater 101-BCA 2. Terjadinya beberapa kegagalan pada line A1011-14" (25P2J) tersebut dinilai sangat mengganggu proses produksi di unit amonia, karena harus dilakukan beberapa kali shutdown untuk dilakukan proses perbaikan, sehingga production rate amonia PT. Petrokimia Gresik akan turun

Hasil analisa dari pihak inspeksi PT. Petrokimia Gresik menyebutkan bahwa, kegagalan terjadi akibat adanya overheating temperatur mencapai $800^{\circ} \mathrm{C}$ dan adanya preexisting crack pada daerah las longitudinal lebih dari $80 \%$ tebal pipa, sehingga dengan adanya tekanan udara dalam pipa dapat mengakibatkan terjadinya pecah (rupture). Overheating hanya akan mempercepat terjadinya pecah pada pipa.

Berdasarkan pada teori tentang metalurgi, bahwa baja tahan karat jenis austenitic pada temperatur $425^{\circ} \mathrm{C}$ sampai $815^{\circ} \mathrm{C}$, kromium karbida akan mengalami precipitates pada batas butir [1], dengan adanya presipitates tersebut daerah sekitar batas butir akan mudah terserang korosi. Adanya tekanan pada lingkungan akan menyebabkan microcrack yang akan menjalar di sekitar batas butir atau sering disebut intergranular stress corrosion cracking.

Analisa pihak inspeksi PT. Petrokimia Gresik tentang penyebab kegagalan pipa udara A312 Type 304H pada line A1011-14" (25P2J) belum mencapai akar permasalahan sebenarnya, karena belum diketahui apa penyebab terjadinya pre-existing crack. Atas dasar hal tersebut maka akan dilakukan penelitian tentang analisa kegagalan pipa udara A312 Type 304H pada line A1011-14" (25P2J) menggunakan metode RCFA (Root Cause Failur Analisys) agar dapat diketahui akar permasalahan sebenarnya.

Dengan metode RCFA dapat mengidentifikasi suatu permasalahan dengan mencari penyebab utama terjadinya kegagalan maupun faktor-faktor yang memungkinkan baik langsung maupun tidak langsung berkontribusi terhadap masalah tersebut [2]. Komparasi antara pengujian material dan identifikasi beban operasi yang bekerja serta identifikasi proses maintenance yang sudah dilakukan pada line A1011-14" (25P2J) adalah skema dasar dari penelitian ini yang digunakan sebagai langkah antisipasi untuk meminimalisir kegagalan dengan kasus yang sama pada komponen ini dikemudian hari.

\section{METODE PENELITIAN}

\section{A. Metode RCFA}

Metode ini digunakan untuk menemukan akar dari permasalahan yang terjadi dengan bantuan tool FTA (Fault 
Tree Analysis) didukung dengan perhitungan tegangan dan pengujian pada material pipa.

\section{B. Perhitungan Tegangan yang Terjadi pada Pipa}

Perhitungan ini bertujuan untuk mengetahui tegangan pada pipa akibat tekanan operasi

\section{Pengujian Fraktografi}

Pemerikasaan fraktografi merupakan pengambilan foto makro dengan menggunakan microscope electron hingga perbesaran maksimal 100x. Pemeriksaan ini bertujuan untuk melihat patahan yang terjadi pada pipa hasil potongan melintang.

\section{Pengujian Metalografi}

Pengujian metalografi dilakukan untuk mengetahui struktur mikro material pipa TP304H dengan perbesaran maksimum 500x dengan menggunakan microscope optic.

\section{E. Pengujian SEM-EDX}

Dilakukan untuk pemetaan distribusi unsur pada sampel dan untuk mengetahui apakah ada unsur korosif yang terdapat pada sampel.

\section{F. Pegujian OES}

Dilakukan untuk mengetahui unsur penyusun SS TP304H, dan untukmengetahui kadar kromium dan karbon yang terkandung pada TP304H.

\section{G. Spesifikasi Material}

Tabel 1.

Data Teknis Pipa Udara

\begin{tabular}{lc}
\hline \hline \multicolumn{1}{c}{ Material Pipa Udara A 1011-14” } & A-321 tipe 304H \\
\hline Diameter & $14 ”$ \\
Schedule & 60 \\
Ketebalan Pipa & $15.6 \mathrm{~mm}$ \\
Tekanan Opeasi & $35.7 \mathrm{~kg} / \mathrm{cm}^{2}$ \\
Temperatur Operasi & $610^{\circ} \mathrm{C}$ \\
\hline \hline
\end{tabular}

Tabel 2.

Mechanical Properties

\begin{tabular}{ccccccc}
\multicolumn{5}{c}{ Mechanical Properties } & & \multicolumn{2}{c}{ Tensile Strength } \\
\hline \hline \multicolumn{2}{c}{ Temperature } & \multicolumn{2}{c}{ Yield Strength } & & Men \\
\hline${ }^{\circ} \mathbf{F}$ & ${ }^{\circ} \mathbf{C}$ & ksi & Mpa & & ksi & Mpa \\
1500 & 816 & 9.9 & 68 & 18 & 124 \\
\hline \hline
\end{tabular}

\section{HASIL DAN PEMBAHASAN}

\section{A. Bentuk Kegagalan}

Ada dua jenis kegagalan yang terjadi pada line A1011-14" (25P2J), yaitu terjadinya crack pada sambungan circumferential dan pecah pada sambungan las longitudinal. Crack pada sambungan circumferential terjadi pada bagian lasan, dan toe crack di base metal saat terjadi pecah di sambungan las longitudinal.

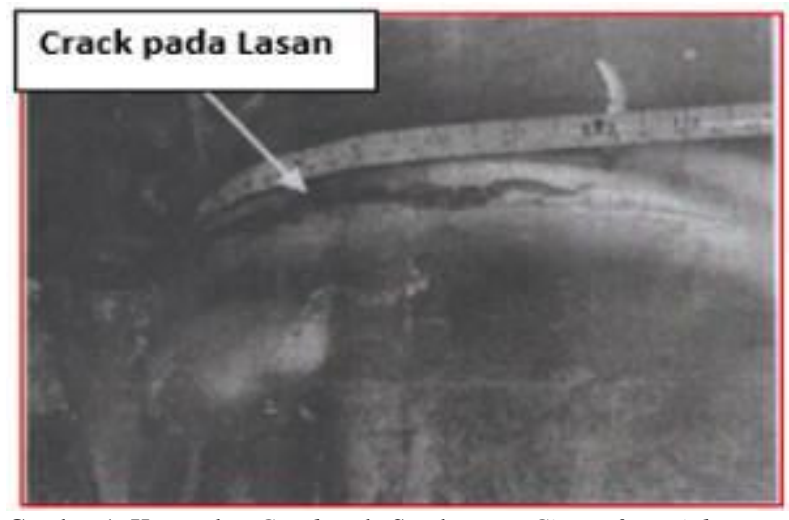

Gambar 1. Kegagalan Crack pada Sambungan Circumferential

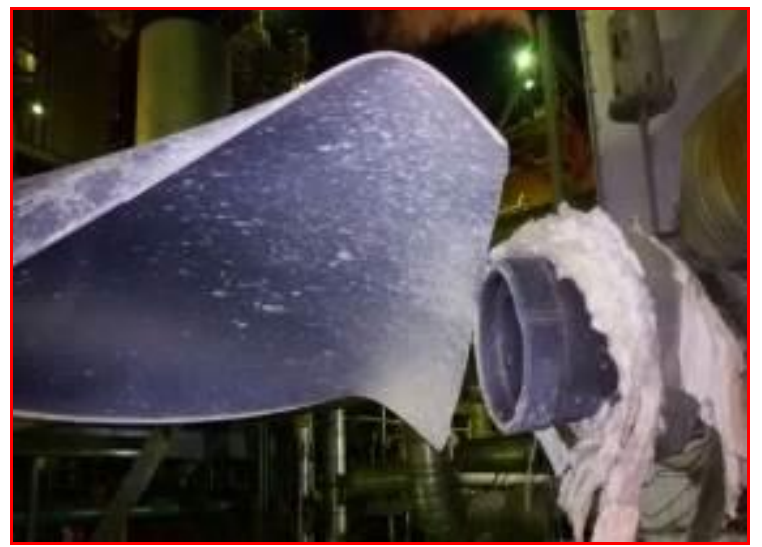

Gambar 2. Kegagalan Pecah pada Sambungan Longitudinal

B. Pengumpulan Data

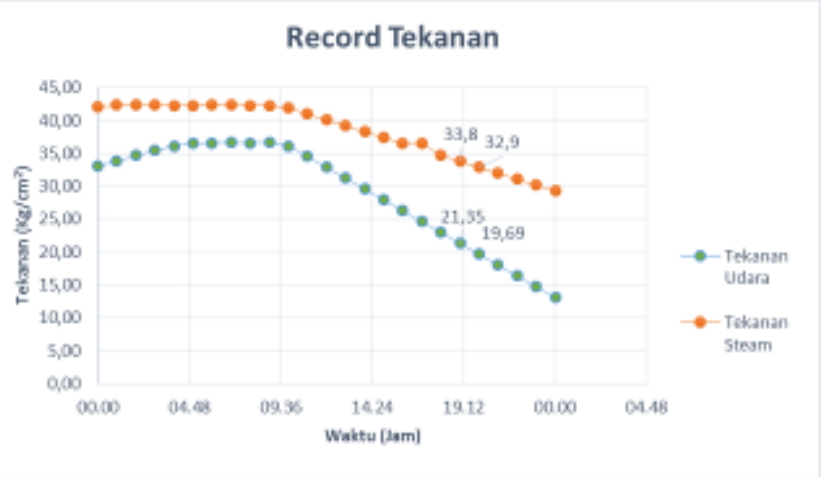

Gambar 3. Record Tekanan saat Terjadi Kegagalan

Gambar 3 menunjukkan adanya penurunan tekanan udara mulai pukul 11.00 WIB, hal ini disebabkan kompresor 101-J mengalami low speed, dengan adanya low speed pada kompresor maka debit udara akan menurun. Penurunnya tekanan dan debit udara maka akan mengakibatkan terjadi kenaikan temperatur pada pipa karena kurangnya fluida yang akan dipanaskan, sehingga pipa mengalami overheat kemudian menyebabkan pecah. 


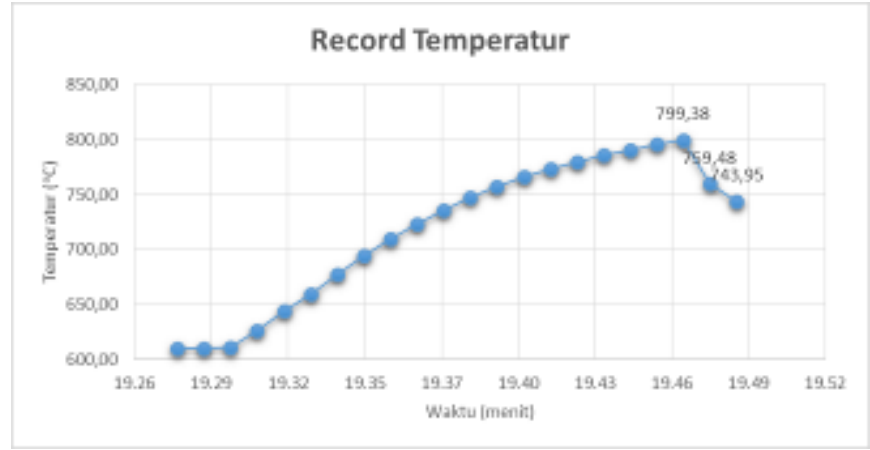

Gambar 4. Record Tekanan saat Terjadi Kegagalan

Adanya penurunan temperatur mengindikasikan bahwa ledakan yang menyebabkan pipa pecah terjadi pada pukul 19.47 WIB. Saat terjadi pecah pukul 19.47 temperatur mencapai $799.38^{\circ} \mathrm{C}$ dan tekanan udara turun hingga diantara $21.35 \mathrm{~kg} / \mathrm{cm}^{2}$ dan $19.69 \mathrm{~kg} / \mathrm{cm}^{2}$.

\section{Identifikasi Penyebab yang Mungkin}

Dari diagram FTA pada Gambar 5 telah mengerucut pada kegagalan material, dimana untuk mengerucutkan permasalahan sebelumnya telah dilakukan metode brainstorming dan interview dengan pihak inspector PT. Petrokimia Gresik.

Gambar 6 menjelaskan diagram FTA kemungkinan penyebab terjadinya crack pada sambungan circumferntial pipa.

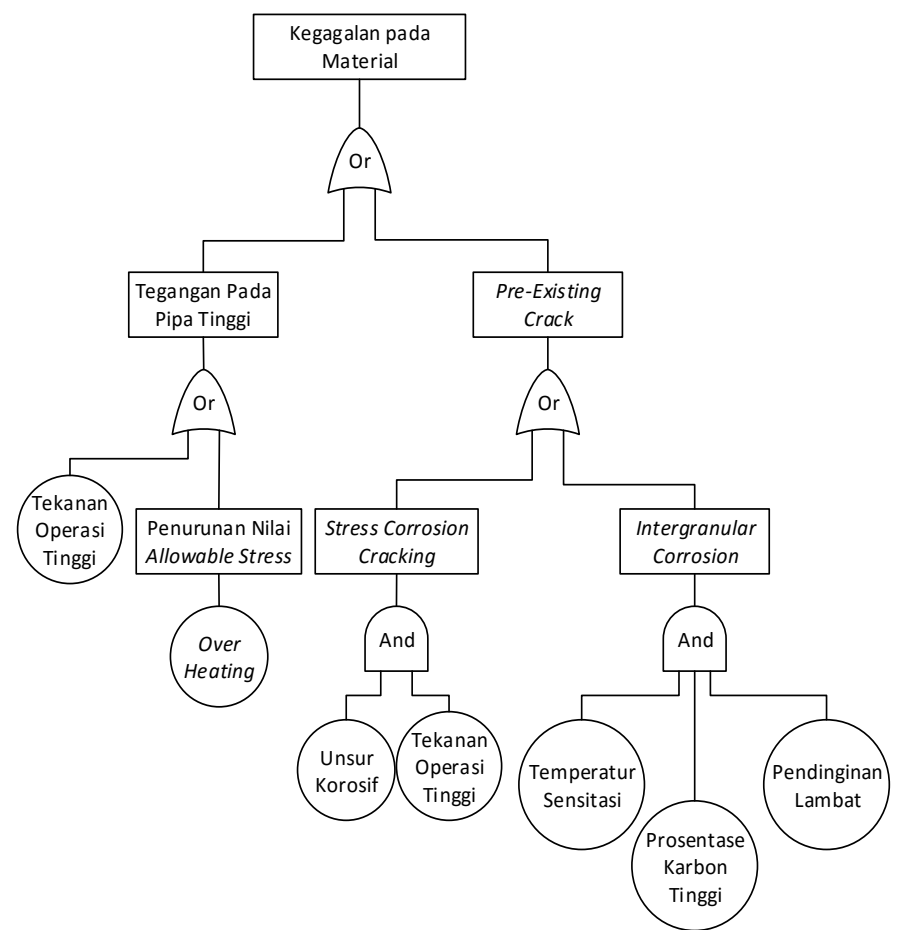

Gambar 5. FTA Kegagalan Crack pada Sambungan Longitudinal

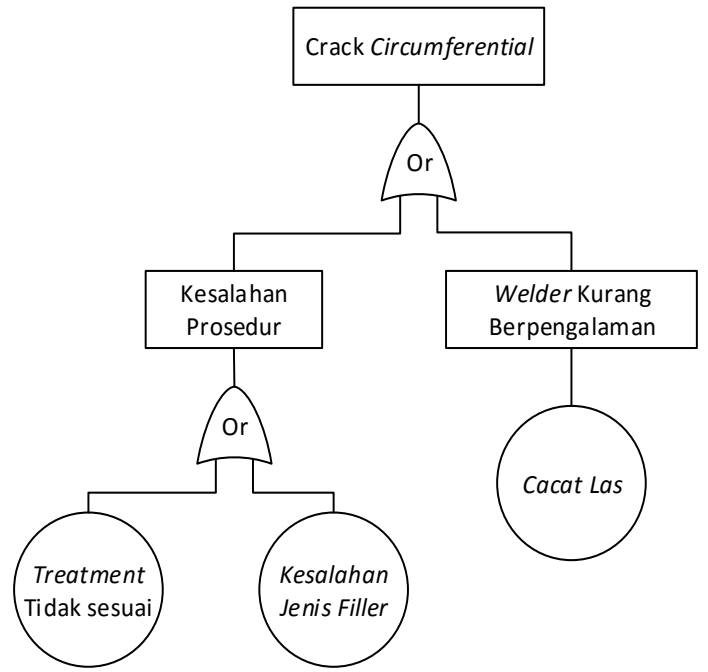

Gambar 6. Kegagalan Crack pada Sambungan Circumferential

\section{Identifikasi Akar Permasalahan}

- Perhitungan Tegangan pada Pipa setelah Mengalami Pengurangan Ketebalan Pipa

Setelah dilakukan pengukuran, ketebalan pipa menglami penipisan menjadi $13.75 \mathrm{~mm}$ atau 0.54 inch, dimana desain awal pipa 0.6inch.

$$
\begin{aligned}
& \sigma_{S H}=\frac{P\left(r_{i}^{2}+\frac{r_{i}^{2} \cdot r_{o}^{2}}{r^{2}}\right.}{r_{o}^{2}-r_{i}^{2}} \\
& \sigma_{S H}=7276.38 p s i
\end{aligned}
$$

Tegangan yang terjadi pada pipa yang disebabkan oleh tekanan operasi sebesar $20.53 \mathrm{~kg} / \mathrm{cm}^{2}$ adalah $7276.38 \mathrm{psi}$, masih dibawah yield strength material pipa pada temperatur $799.38^{\circ} \mathrm{C}$ yaitu 9900 psi.

- Perhitungan Tegangan pada Pipa setelah Mengalami Pengurangan Ketebalan Pipa dan Pre-existing Crack

$$
\begin{gathered}
\sigma_{S H}=\frac{P\left(r_{i}^{2}+\frac{r_{i}^{2} \cdot r_{o}^{2}}{r^{2}}\right)}{r_{o}^{2}-r_{i}^{2}} \\
\sigma_{S H}=12978.55 \mathrm{psi}
\end{gathered}
$$

Tegangan pipa yang terjadi 12978.55 psi melampaui yield strength material yaitu 9900 psi, akan tetapi masih dibawah tensile strength material yaitu 18000 psi.

- Hasil Pengamatan Fraktografi menggunakan SEM

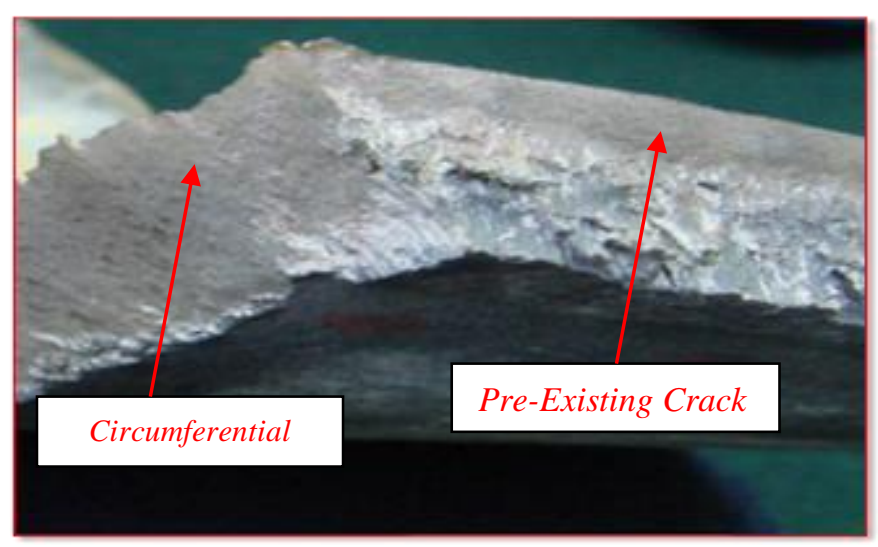

Gambar 7. Titik Pengamatan Fraktorafi 


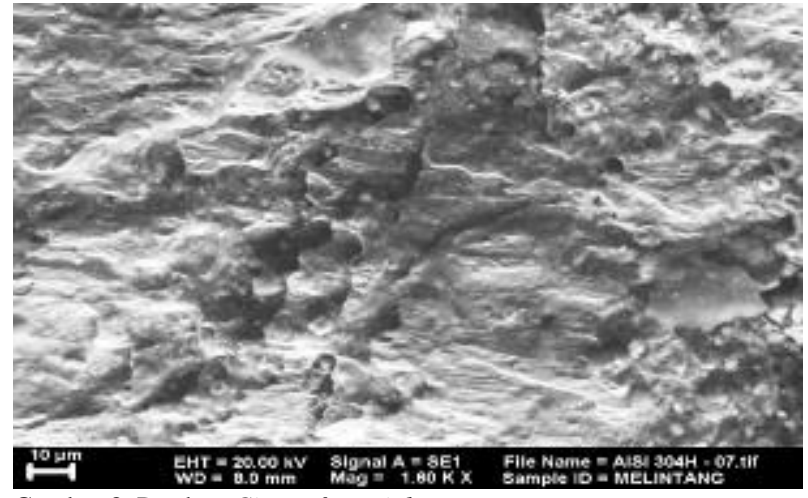

Gambar 8. Patahan Circumferential

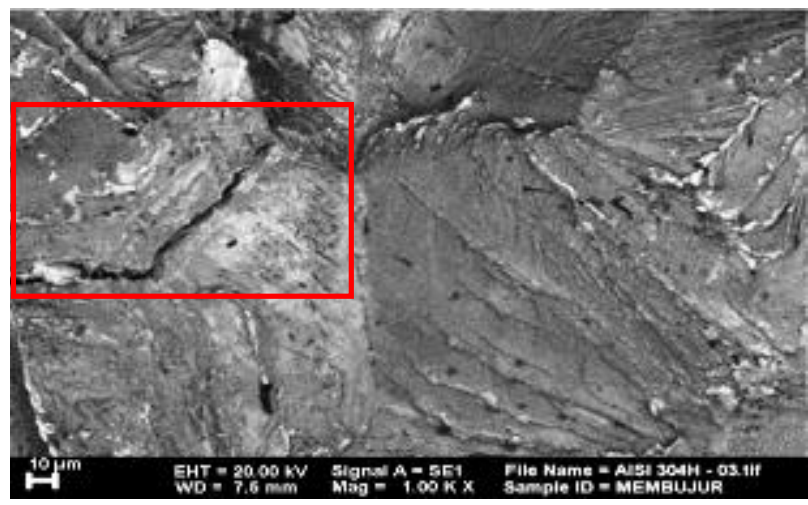

Gambar 9. Pre-existing Crack Patahan Longitudinal

Patahan circumfeential perbesaran 1600x berdasarkan ASM Handbook Volume 12 - Fractrography bentuk patahan dengan ciri-ciri tersebut merupakan bentuk patahan akibat proses geser (shear process). Bentuk patahan yang terjadi akibat tegangan geser, sehingga pada daerah circumferential bukan merupakan awal terjadinya fracture, akan tetapi patahan pada daerah circumferential terjadi akibat dari adanya patahan lain.

Hasil pengamatan (scanning electron microscope) SEM dengan perbesaran 1000x pada patahan halus yang merupakan pre-existing crack menunjukkan pola craking disebabkan sliding pada batas butir. Sliding pada batas butir diakibatkan karena lemahnya batas butir sehingga dapat mengalami deformasi.

\section{- Pengamatan Struktur Mikro}

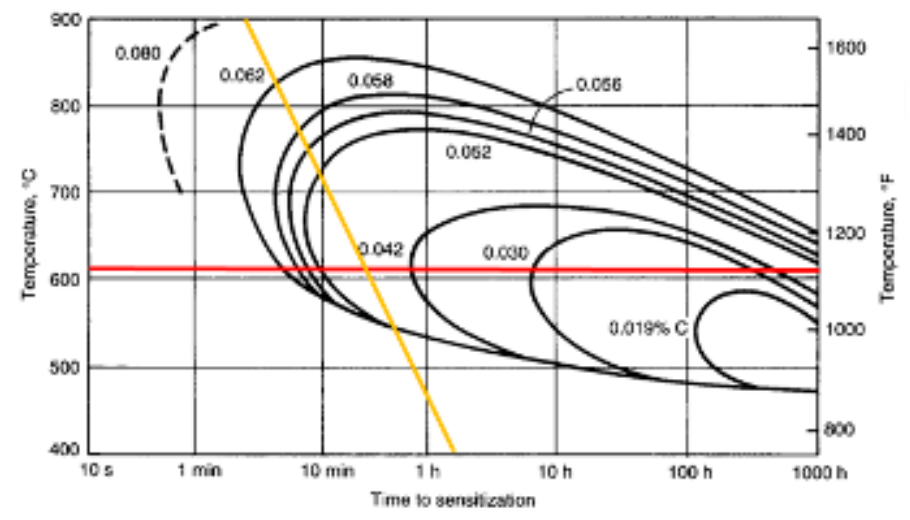

Gambar 10. Diagram Terjadinya Presipitasi Karbida Krom

Garis merah menggambarkan temperatur operasi udara dan garis kuning merupakan pendinginan pada proses pengelasan.
Hasil interview yang dilakukan dengan bagian pengelasan. Garis merah dan kuning pada Gambar 8 menunjukkan bahwa garis tersebut melewati daerah sensitasi.
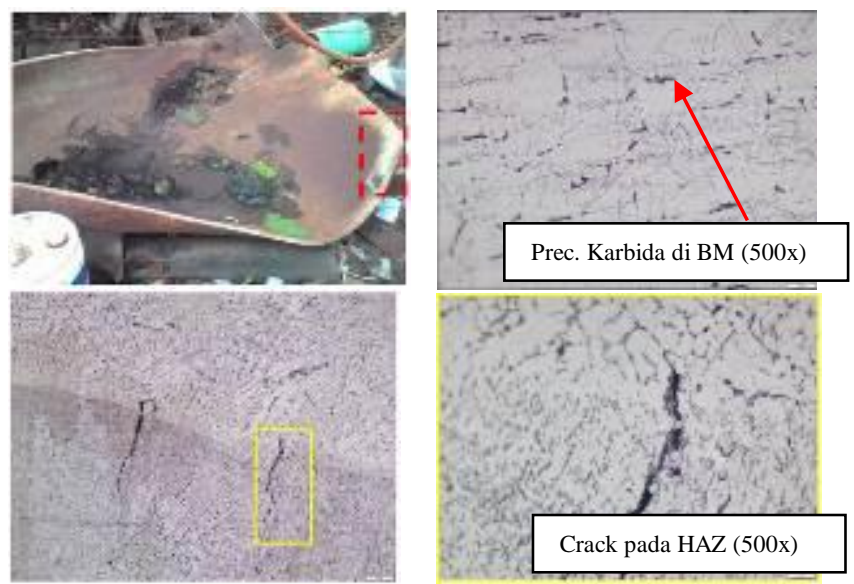

Gambar 11. Hasil Pengujian pada Sampel di Titik ke 1

Hasil perbesaran pada sampel di titik 1 terdapat adanya crack yang menjalar pada batas butir mulai dari HAZ melewati fusion line sampai berhenti di fusion zone. Perbesaran 500x pada fusion zone atau welded menunjukan adanya delta ferrit. Pada perbesaran 500x daerah HAZ terlihat adanya presipitasi karbida krom pada batas butir. Perbesaran 500x presipitasi karbida krom terlihat sangat banyak. Hal tersebut yang menyebabkan daerah disekitar batas butir menjadi lemah dan terjadi retak pada daerah tersebut. Retak yang menjalar pada batas butir disebut dengan IGSCC (intergranular stress corrosion cracking).
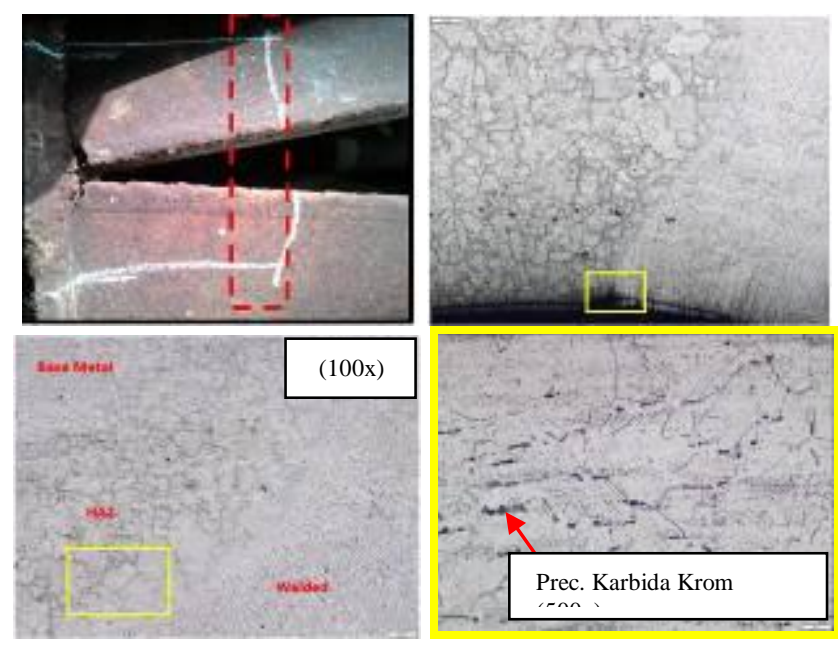

Gambar 12. Hasil Pengujian pada Sampel di Titik ke 2

Sampel diambil dari bagian las longitudinal, dari hasil pengamatan metalografi dengan perbesaran 100x pada terlihat adanya initial crack pada sisi pipa bagian dalam. Initial crack yang terjadi pada daerah HAZ dan menjalar melalui batas butir. Pada perbesaran 100x menunjukkan butir HAZ berukuran besar dan tidak homogen dan butir base metal yang berukuran lebih kecil dan homogen. Besarnya butiran HAZ maka butir akan rentan terjadi dislokasi dikarenakan batas butir yang menjadi penghambat pergerakan dislokasi sedikit, sehingga 
logam akan mudah terdeformasi. Mudahnya bagian HAZ untuk terdeformasi dan dengan adanya presipitasi karbida krom pada batas butir mengakibatkan initial crack muncul pada daerah tersebut. Perbesaran 500x terlihat pada daerah HAZ terdapat adanya presipitasi karbida krom.

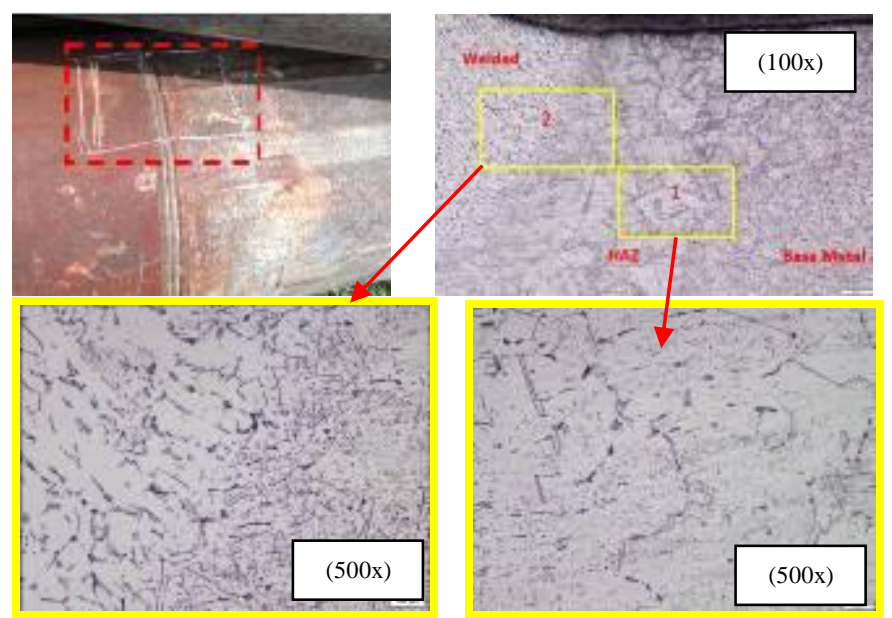

Gambar 13. Hasil Pengujian pada Sampel di Titik ke 3

Sampel diambil dari sambungan longitudinal pipa yang masih utuh, pada pengamatan dengan perbesaran 100x tidak terlihat adanya cacat pada lasan maupun base metal, hanya saja butiran pada HAZ terlihat lebih besar dibandingkan dengan base metal. Perbesaran 500x menunjukkan pada daerah HAZ terjadi presipitasi karbida krom.

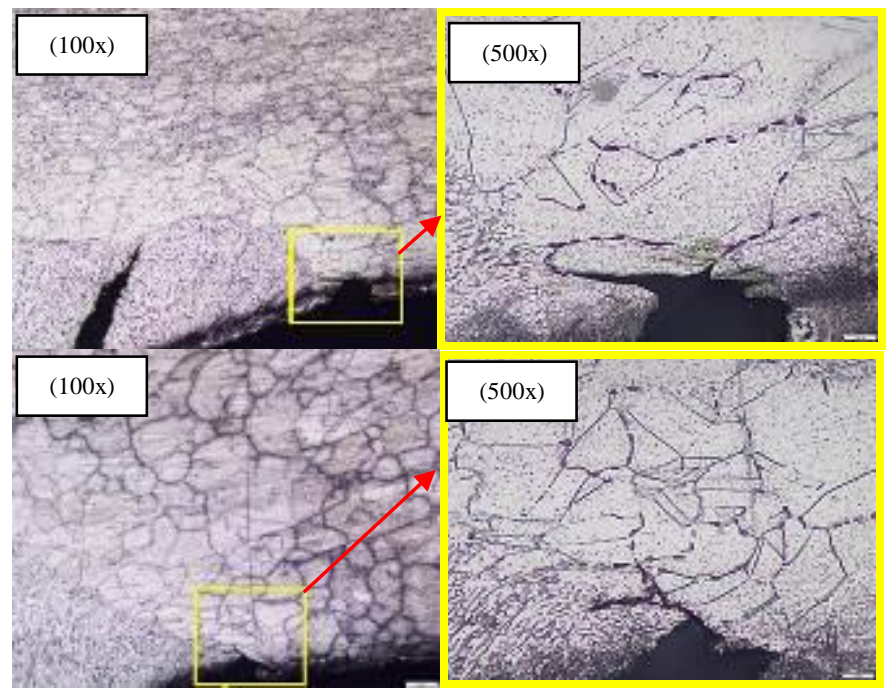

Gambar 14. Hasil Pengujian pada Sampel di Sambungan Reinforce

Sampel terdapat adanya initial crack yang menjalar pada batas butir daerah HAZ dan terdapat presipitasi karbida krom pada daerah tersebut. Hasil pengamatan juga terlihat adanya undercut. Adanya undercut pada lasan dapat mengurangi kekuatan sambungan las, dikarenakan tegangan akan terkonsentrasi pada daerah tersebut, sehingga berpotensi terjadinya retak. Undercut pada proses pengelasan disebabkan saat melakukan capping dengan kecepatan yang rendah, sehingga base metal akan ikut mencair. Adanya initial crack dan presipitasi karbida krom pada daerah HAZ retak akan menjalar melalui batas butir, sehingga hal tersebut merupakan penyebab terjadinya toe crack saat terjadi pecah pada pipa. Proses pecahnya daerah circumferential diyakini selain akibat dari tegangan geser juga akibat adanya initial crack yang terjadi pada HAZ.

Dari hasil pengujian sampel pada empat titik ditemukan adanya presipitasi karbida krom pada batas butir baik di daerah HAZ maupun base metal. Adanya presipitasi karbida krom pada batas butir membuat daerah tersebut menjadi lemah dan timbul intergranular cracking. Pre-existing crack yang terjadi pada sambungan longitudinal pipa setelah diteliti juga terdapat adanya intergranular cracking. Dari hasil analisa tersebut menyatakan bahwa kegagalan bukan hanya karena tegangan dan adanya pre-existing crack, akan tetapi kegagalan disebabkan karena intergranular corrosion yang menyebabkan kekuatan material menurun.

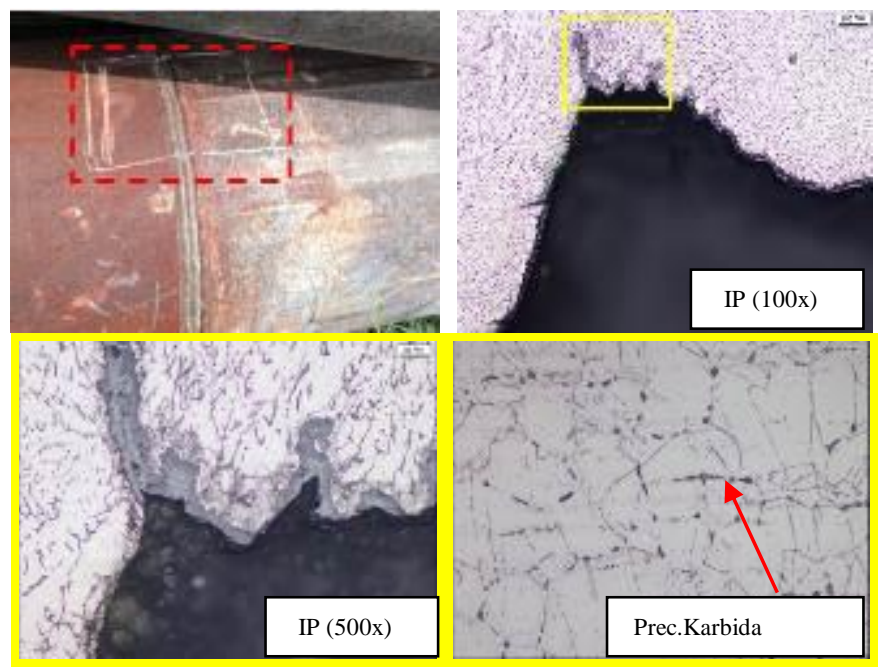

Gambar 15. Hasil Pengujian pada Sampel Potongan Circumferential

Sampel diambil dari bagian circumferential, pengamatan dilakukan untuk menemukan penyebab terjadinya crack pada las circumferential. Hasil pengamatan fotografi setelah dilakukan pemotongan sampel menunjukkan adanya incomplete penetration pada layer pertama proses pengelasan. Incomplete penetration disebabkan karena prosedur pengelasan yang kurang baik, biasanya diebabkan karena saat pengelasan tidak melakukan preheat, sehingga degan kecepatan pengelasan yang tinggi dan logam dalam keadaan dingin cairan filler akan cepat membeku dan tidak dapat berpenetrasi sampai ke dalam. Dengan adanya incomplete penetration pada daerah lasan, maka dilakukan pengamatan lebih lanjut pada daerah tersebut dengan pengamatan metalografi. Hasil dari pengamatan metalografi dengan perbesaran 100x menunjukkan ujung-ujung incomplete penetration terlihat tajam, setelah dilakukan perbesaran hingga 500x terlihat dari ujung-ujung tajam tersebut menjalar crack menuju dalam bagian fusion zone. Selain itu pada bagian HAZ dengan perbesaran 500x sangat jelas terdapat presipitasi karbida krom pada batas butir. 


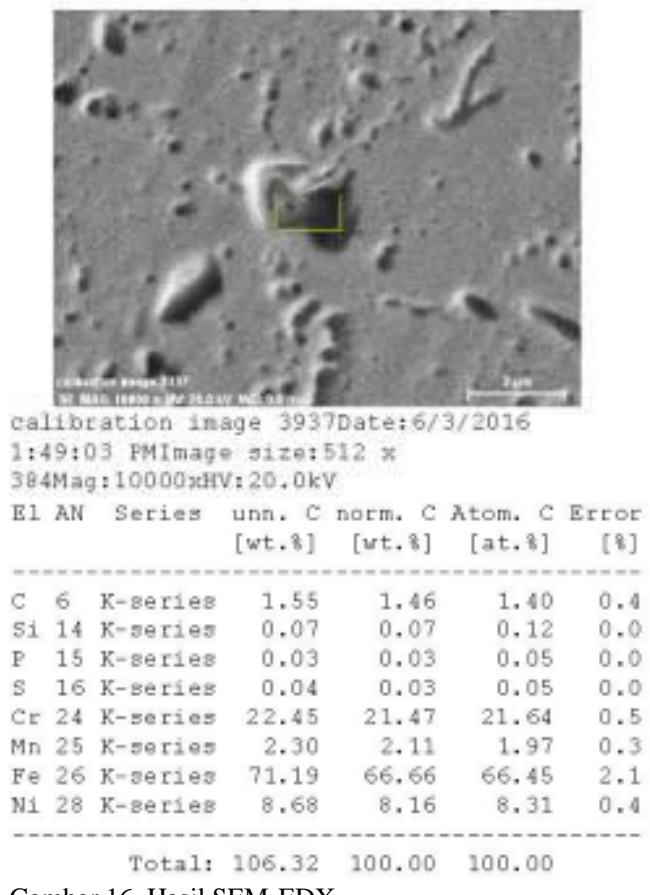

Gambar 16. Hasil SEM-EDX

Tabel 3.

Perbandingan Hasil OES dan EDX

\begin{tabular}{ccc}
\hline \hline Unsur & Pengujian OES $(\%)$ & Pengujian EDX $(\%)$ \\
\hline $\mathrm{C}$ & 0,049 & 1,40 \\
$\mathrm{Cr}$ & 18,16 & 21,64 \\
$\mathrm{Mn}$ & 1,608 & 1,97 \\
$\mathrm{P}$ & 0,01 & 0,05 \\
$\mathrm{~S}$ & 0,025 & 0,05 \\
$\mathrm{Si}$ & 0,479 & 0,12 \\
$\mathrm{Ni}$ & 8,52 & 8,31 \\
$\mathrm{Fe}$ & 71,149 & 66,45 \\
\hline \hline
\end{tabular}

Setelah dilakukan pengujian EDX pada bagian endapan berwarna hitam tersebut hasilnya adalah terdapat unsur $\mathrm{C} 1.4 \%$ dan unsur $\mathrm{Cr} 21.64 \%$, apabila dibandingkan dengan hasil pengujian OES (Optical Emission Spectrometry) unsur C $0.049 \%$ dan $\mathrm{Cr} 18.16 \%$. Hasil dari EDX menunjukkan adanya peningkatan persentase unsur karbon dan krom yang signifikan pada batas butir, hal ini menunjukkan pada daerah tersebut terdapat presipitasi karbiada krom. Hasil pengujian EDX juga tidak menunjukkan adanya unsur korosif $\mathrm{Cl}$ (cloride), sehingga pre-existing crack bukan terjadi karena SCC (Stress Corrosion Craking) melainkan karena IGSCC (intergranuar stress corrosion craking).

\section{E. Solusi dan Rekomendasi}

Penggantian pipa TP304H welded menjadi TP304H seamless dapat meningkatkan kekuatan pipa. Hasil penelitian membukikan kegagalan terjadi pada daerah HAZ sambungan longitudinal yang disebabkan intergranular corrosion, selain itu kegagalan pada pipa juga dipengaruhi dengan pipa yang sudah beroperasi lebih dari 15 tahun. Penggantian dengan TP304H seamless pipe dirasa lebih efektif karena dengan biaya yang minimal dapat menaikkan kekuatan pipa. Tidak adanya sambungan longitudinal pada pipa seamless, maka kegagalan serupa dapat dicegah dan akan menambah umur pakai pipa.
Untuk kegagalan pada sambungan circumferential, hal tersebut dapat dicegah dengan penggunaan prosedur yang sesuai pada proses reweld ataupun proses pengelasan pada reinforce.

\section{KESIMPULAN}

Dari penelitian yang telah dilakukan dapat ditarik kesimpulan bahwa terdapat beberapa penyebab terjadinya kegagalan, yaitu: a.Hasil pengujian EDX/EDS (Energy Dispesive X-Ray Analysis) membuktikan adanya peningkatan unsur $\mathrm{C}$ dan $\mathrm{Cr}$ pada batas butir.

b. Kegagalan pada line A 1011-14" bukan hanya disebabkan oleh adanya tegangan dan pre-existing crack tetapi juga karenakan adanya IGSCC (intergranular stress corrosion cracking), dan juga disebabkan oleh umur pipa mencapai lebih dari 15 tahun. Hasil pengujian EDX membuktikan adanya IGSCC (intergranular stress corrosion cracking)

c.Hasil pengamatan struktur mikro bagian las circumferential menunjukkan adanya incomplete penetration pada fusion zone, setelah dilakukan perbesaran 500x cacat las tersebut berujung runcing yang menyebabkan crack pada fusion zone. Hal tersebut menjadi penyebab terjadinya crack pada las circumferential pipa.

Solusi dan rekomendasi yang akan diajukan agar kegagalan yang serupa tidak terulang lagi adalah sebagai berikut:

a.Penggantian pipa TP304H welded menjadi TP304H seamless dapat meningkatkan kekuatan pipa. Penggantian dengan TP304H seamless pipe dirasa lebih efektif karena dengan biaya yang minimal dapat menaikkan kekuatan pipa. Tidak adanya sambungan longitudinal pada pipa seamless, maka kegagalan serupa dapat dicegah dan akan menambah umur operasi pipa.

b. Untuk menaggulangi terjadinya crack di setiap joint maka proses pengelasan harus disesuaikan prosedur.

\section{DAFTAR PUSTAKA}

[1] Denny A. Jones. Principles and Prevention of Corrosion Second Edition. University of Nevada: Prentice Hall, Upper Saddle River.

[2] Mobley Keith. R., Lindley R. Higgins dan Darrin J. Wikoff. 2008. Maintenance Engineering Handbook Seventh Edition. New York: Mc Graw Hill.

[3] ASM. 1987. Handbook Volume 12 Fractography. ASM International the Materials Information Company. Amerika

[4] Brook, R.C dan Choudhury, A. 2002. Failur Analisys of Engineering Material. New York: Mc Graw-Hill.

[5] Fontana, Mars G. 1978. Corrosion Engineering. McGraw-Hill Inc. 